\title{
EVALUATING CRITICAL FACTORS IMPACTING REAL ESTATE DEVELOPMENT DECISIONS
}

\author{
Jigar V Pandya \\ Department of Civil Engineering, School of Technology \\ Pandit Deendayal Petroleum University, Gandhinagar, India \\ e-mail:jigarpandya18@gmail.com \\ Vikram M. Patel \\ Adani Institute of Infrastructure Engineering and Management \\ Gujarat Technological University, Ahmedabad, India \\ e-mail:vikram.patel@aiim.ac.in
}

\begin{abstract}
We find that critical factors affecting real estate project decisions can vary while market changes in the city of Ahmedabad have led to the majority of landmark buildings facing obsolesce, redevelopment and spatial redundancy. Case studies can assist in data collection in the cultural context and accommodate indirect observations of the variables analyzed in the early stages of research (Teegavarapu \& Summers, 2008; Rowley, 2002). Decisions have led to capital losses for some, while bringing about profitable opportunities for developers who take timely risks.

We also find that the land pooling technique used by the State in city development has successfully promoted land banking for public purpose but has also contributed to speculative land price appreciation. AHP rankings show that the surveyed practicing developers prioritized location factors such as neighborhood character and availability of land above land use zones and land auctions. Among project factors, FAR (Floor Area Ratio), abutting road width and road frontage of the land ranked higher compared to building design. In the professional practice category, the availability of finance, the timing of project announcement and past project experience of the developers ranked higher compared to brand value and speculation.
\end{abstract}

Key words: project decisions, critical factors, developers, case studies, AHP method.

JEL Classification: D46, E39, O22, R14.

Citation: Pandya, J. V., Patel, V. M. (2020). Evaluating Critical Factors Impacting Real Estate Development Decisions. Real Estate Management and Valuation, 28(1), 112-126.

DOI: https://doi.org/10.1515/remav-2020-0010

\section{Introduction}

The optimum use value of land and property is derived as a result of supply-demand dynamics (Pagourtzi et al., 2003). Literature on urban planning in India (Batra, 2009; Ahluwalia \& Kanburand, 2014; Bholey, 2016) suggests that the goals for urbanization are focused towards aspects of housing density, commercial activity and industrial zoning. However, the urban land use for real estate developments is decided by the practicing developers, each of whom have an established brand value among their prospective property buyers. This could be attributed to the quality and the confidence that clients have when buying a house, bearing in mind that it was developed by professionals (Risper, 2012). However, land use controls which promote housing bubbles needs to be realigned to larger economic goals, and there seems to be a clear absence of these initiatives, be it the government or the social strata (Jansen, 2013). 
Evidence from research literature, citing case studies from United Kingdom, suggests a concept of "Hope Value," where a future additional value arising due to favorable planning legislature and land use changes allows its inclusion in the present market value assessment (Grzesik, 2014). The argument on the Highest and Best Use (H\&BU) values have also been appropriately defined in internationally recognized valuation standards, such as the International Valuation Standards Council (IVSC) and The European Group of Valuers' Association (TEGoVA). Such assumptions allow for a rise in the value of a property when there is reasonable opportunity for growth in the near future leading to speculative investments. The highest and best use of such properties is usually an individual assessment, influenced by social context, culture, environment, historical background, economic viability and its emotional association (Szczepańska, 2012). However, the aspect of uncertainty cannot be ruled out within the assessment of "Hope Value" using the principle of "Highest and Best Use." (Grzesic \& Źróbek, 2017)

\section{Literature review}

Project decision on a given land parcel and choices made with reference to site context and its architecture have a bearing on its final construction costs and operation, and are responsible for the marketing, occupancy and feasibility of the project (CMHC, 2014). In USA, post the financial crisis of 2008, the results showed that, in the State of California, stringent land use controls promoted high and volatile residential values (Mills, 2009). As an accounting practice for tax filing purposes, it has been researched that real estate properties showed $2-4 \%$ depreciation of the building annually, where residential buildings were susceptible to faster depreciation when compared with commercial establishments (Crosby \& Devaney, 2011). In areas of the city where building byelaws are constrained, depreciation is much lower compared those where there is greater freedom of development (Bokhari, 2014).

A literature review may not be enough to identify these factors; hence a case study approach was used to derive the critical factors that impact developers. Research methods suggest that case studies are frequently used in process design research to analyze a phenomenon, to generate a hypothesis, and to validate a method. They assist in data collection in the cultural context and accommodate indirect observations of the variables used in the analysis (Teegavarapu \& Summers, 2008). The case study technique is also useful in early stages of research on a topic, especially when a fresh perspective is needed, while imparting critical knowledge (Rowley, 2002). An African study (Risper, 2012) on professional backgrounds does not look into the decision of project selection leading to the supply of houses. An Asian context suggests that developers presell real estate projects (pre and during construction, before completion) as a marketing strategy to hedge the risks connected with competition (Lai et al., 2004), and subsequently maintaining real estate prices when the market sales are slow (Somerville, 2001). While these are sale strategies, none of these studies clearly addresses any findings on factors which may be considered crucial at the time of project conceptualization and timing of the development. Residential property developers in Australia are likely to manage uncertainties and risks (Mintah, 2018), examine flexibility as a risk management tool, and evaluate the receptiveness for decision making. Real estate transaction linked price indices tend to a show stronger growth and sharper declines over the course of the cycle, and are typically two to four times more volatile (Devaney, 2014).

Mueller, in his study, suggests that, due to a supply-demand imbalance, when market conditions are slow, developers are likely to slow construction activity and renew capital flows to restore the market conditions (Mueller, 2002). The study does not discuss the supply-demand equilibrium with respect to the timing of the project announcement. An Indian study conducted by CRISIL emphasizes that developers are likely to make project announcements based on their land holdings rather than market timing (Crisil, 2007). This report lacks any evidence on the factors which may have motivated the developers to announce multiple projects at a given time, despite not having an existing land bank. A study on perception (Malpezzi \& Wacher, 2002) suggests that developers and investors are likely to speculate real estate developments based on supply conditions. Markets with more responsive regulatory environments, or less natural constraints (from physical geography), are likely to display lesser volatility in prices, supply and demand, and subsequently lower speculation. The study does not take into account the contextual aspect of participants in a market cycle, nor does it cover any psychological profiling, neither risk taking, nor any past experience of the developers 
practicing in the market. Moreover, researchers are yet to measure speculation accurately in regards to the real estate markets of India.

\section{Data and Methods}

We set out with a research hypothesis that critical factors impacting project decisions can vary with every project and its site conditions; however, their priority ranks can help us validate property valuation parameters, helping us to derive its potential market value with reference to real estate projects. The objective of the research was to identify and evaluate the critical factors impacting project decision and to evaluate their categorical priority ranks by surveyed practicing developers.

\subsection{Data collection and analysis}

Ahmedabad city, India, with a population of over 5.5 million as per the Indian Census 2011, with over 1.1 million households (AMC, 2018) and having an urban agglomeration of more than $600 \mathrm{~km}^{2}$ (Auda, 2014), was chosen as the study area to achieve the objectives of the research, as it offers the demographic and cultural diversity required for the investigation. Data on case studies are collected from offices of urban local bodies, personal interviews with the developer of the project, residents, contractors and engineers who worked on the project. The questionnaire for the interviews was open ended with information drawn on the history, constraints and spatial events on the project site.

Respondent survey techniques using Likert Scale and Analytic Hierarchy process have proved to give valuable insights (Bucheli, 2016) in classifying and ranking critical criteria (Bunyan \& Yalpir, 2016). Factors identified from the case studies were further prioritized by conducting a response sample survey of 30 experienced, practicing developers by using Ratio Scale Prioritization Method (RSMP); a technique of Analytical Hierarchical Processing (AHP). All top ranked factors among these were considered for further testing.

\subsection{Case study 1: Patang revolving restaurant \& Chinubhai center}

The case study explores the urban problems of obsolesce, redevelopment and urban renewal. It provides insight into economic potential of an iconic design due to spatial redundancy.

\subsubsection{Background}

The Chinubhai Commercial Center has a total of $8220 \mathrm{~m}^{2}$ (HCP) of built-up area, within which only $562 \mathrm{~m}^{2}$ of total floor space is dedicated to the Patang Restaurant. It was conceived and built in the early 1980s and was the tallest building in 1989 with a height of 67 meters when building byelaws permitted buildings only as high as 30 meters. The project was designed by the architectural firm HCP designs and was meant to symbolize Ahmedabad city's vibrant kite flying festival, to promote tourism and lifestyle in the city, and to maximize the benefits arising from the economic potential of the Ashram road running parallel to Sabarmati river. The structure embodies symbolic design value that remains relevant even nowadays. The plan, elevation and recent picture of Patang restaurant as part of Chinubhai Center is shown in Figure 1.

\subsubsection{Development Status}

In early 2000s, after two decades in service, Patang restaurant was nonoperational due to a decline in fine dining experience preferences, escalations in food prices and the changing lifestyle of citizens. Following the 2001 earthquake damage which occurred to the city, patrons were not keen on spending an hour of dining experience at the highest culinary point in the city. Eventually, the high operational costs resulted in its business closure. The landmark structure stood tall during this tough time and was put up for sale on the real estate market. Valuers and property appraisers had a tough time ascertaining an offer price for the building, while the market had no likely buyers for this property. The key issues were that the Patang Restaurant did not have any exclusive land area, and was merely a vertical RCC (Reinforced Cement Concrete) elevator shaft with a two story expanding apex as the built up area. A building without exclusive land rights, limited carpet area and iconic structural value was difficult to appraise. The owners of the restaurant offered it as a corporate headquarters to few companies to boost their brand image, but the restricted carpet area impeded its use option to operate as a standalone corporate office space for even a mid-size company. 

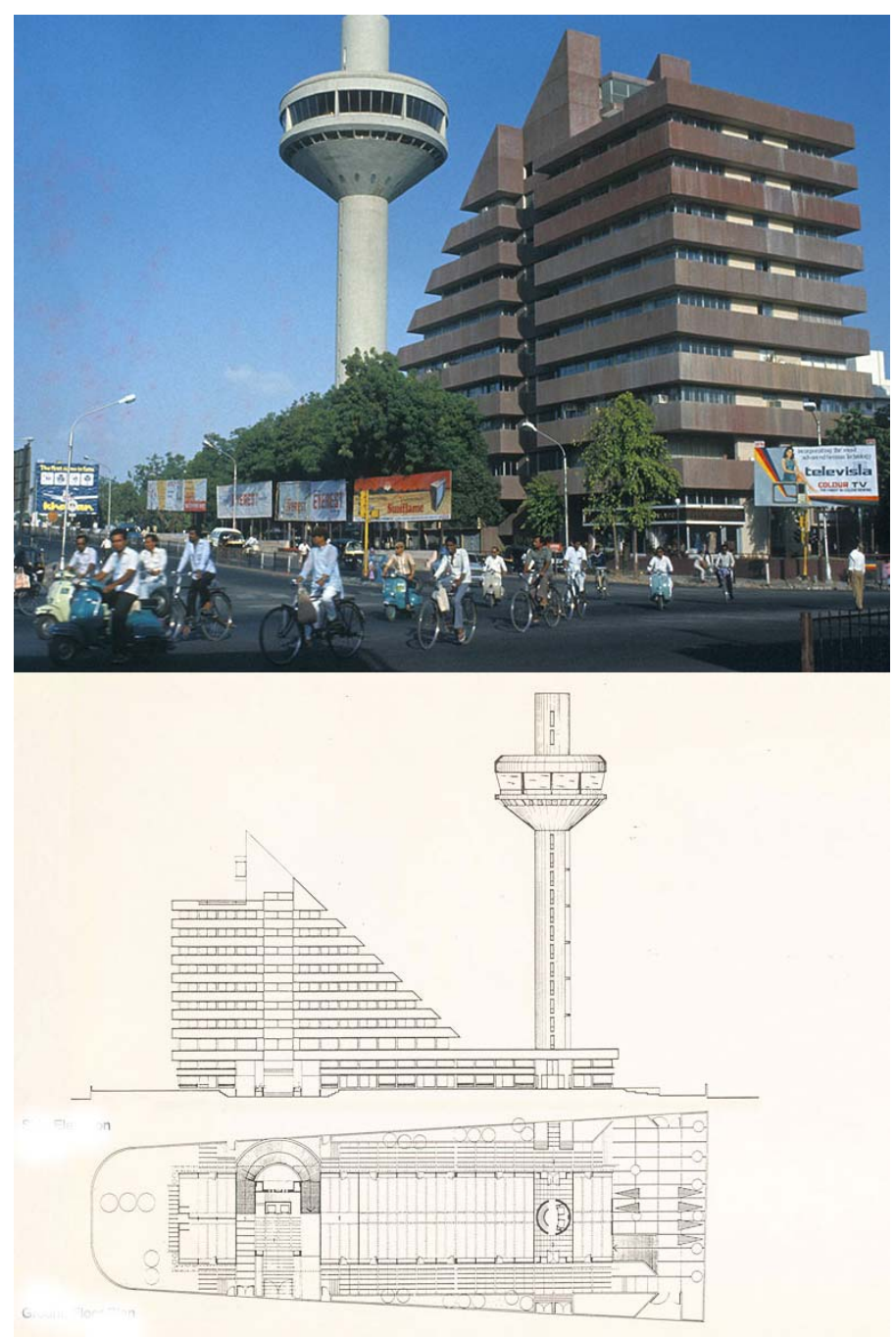

Fig. 1. Case Study 1 - Patang Restaurant. Source: (HCP).

\subsubsection{Decisions by Stakeholders}

In year 2005, after 3 years of obsolescence, Patang was purchased by Neelkanth developers, having business operations in hotels and real estate, and later leased to the food catering agency. The buyer disclosed that the purchase decision would not allow them to make any real estate gains on the site as it was not economically viable to demolish it and redevelop it, as there was no additional FAR (Floor Area Ratio) available for redevelopment. Strategically, it helped them consolidate their brand image and benefit on several other projects - having exhibited the goodwill to own and operate a property of historic cultural value to the citizens of Ahmedabad. Patang restaurant opens up a debate on understanding the difference between the perceived value, realized value and market value of the property. The perceived value, as seen by the previous owner was much higher while the realized value was much lower than the prevailing market value. How can an iconic design structure sell short?

\subsubsection{Critical Factors}

Location analysis, market conditions and interviews with professionals associated with the project decisions led to the discovery of following critical factors such as: 1) Availability of land , 2) Availability of FAR, 3) Scope of redevelopment, 4) Brand value, 5) Design, and 6) Choice of development (project). 


\section{$S$ sciendo}

\subsection{Case Study 2: Jay Shefali row houses and Siddhivinayak complex}

This case study summarizes the impact of land economics on urban housing resulting from urban planning activities in a growing city.

\subsubsection{Background}

Jay Shefali row houses were built by H.K. Constructions on the urban fringe of Ahmedabad city between the years 1974-78; they were a luxury housing project with a private swimming pool, resonating the social ethos of Ahmedabad old city Pol living. The architect, in his design, conceptualized a linear pattern of an attached housing system (Figure 2), 50 housing units, with each house sharing a common wall on either side of their residences resembling old city Pol houses of Ahmedabad (Kamal \& Mngaldas, 2014). Built using composite technology of RCC and brickwork, the housing project was meant to last at least 60 years. Resident interviews revealed that, at the time of project inception, this was a novel concept as these were neither apartments (condominiums) nor bungalows (townhouses). The housing units were scalable; the modular design allowed residents to construct an additional bedroom in their backyard as well as a terrace, should the family size increase in the future, an occupancy design which was pre-approved at the local municipal office. This uniqueness motivated buyers to move from the closed net communities in old Pol houses to what was then a city fringe, offering cleaner air and open spaces.

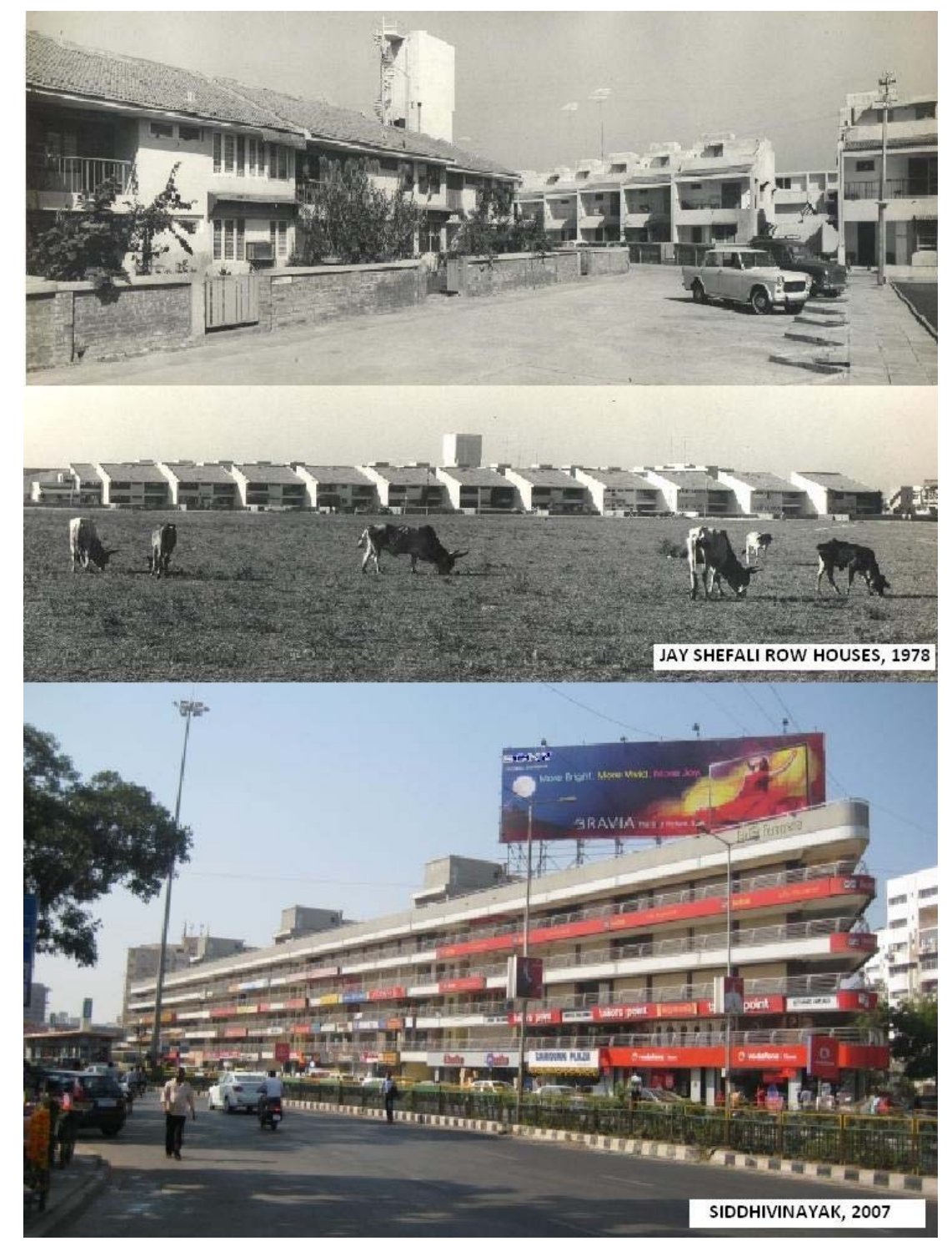

Fig 2: Jay Shefali Row Houses .Source: Kamal Mngaldas (2014) and Siddhivinayak. 


\subsubsection{Development Status}

In the year 1978, the project was abutting a 15 meter Satellite road which was revised to 30 meters width in the year 1987 as per new AUDA (Ahmedabad Urban Development Authority) Development Plan. These changes affected the residents as their front yard area had to be surrendered to AUDA for the road widening. The compensation received for the land surrendered was at the existing "Jantri" 1 (Circle rate) values, which were 75\% lower compared to the market value at the time. In year 2002, AUDA further revised the width of the Satellite Road to 40 meters from existing 30 meters. The existing FAR of 1.0, as per the 1987 Development plan, was updated to 1.8 in the new Development Plan of 2001. The rapid urban changes occurring in the city lead to traffic volumes which were difficult to manage on the Satellite road. These changes, however, meant that 11 houses (admeasuring $4758 \mathrm{ft}^{2}-46340 \mathrm{ft}^{2}$ each) abutting the $40 \mathrm{~m}$ wide Satellite road were to lose more than $60 \%$ of their land and built-up area. This meant that these houses would have to be fully demolished and compensated for. For a project which is hardly 2 decades old, the second revision offered compensation which was $33 \%$ of the existing market value due to the non-revision of Circle rates. Figure 2 shows the layout plan for the houses and the phases of road widening of Satellite road.

\subsubsection{Decisions by Stakeholders}

All of the 11 house owners decided to sell their homes to a single buyer in order to get any potential value for their property. This meant a developer had to undertake a potential redevelopment for the entire 50-owner housing project. A well-known media house successfully negotiated and purchased all the 11 houses from their respective owners at a fair market value, to develop a commercial redevelopment project Siddivinayak under the registered firm named GCCL Construction \& Realities Pvt. Ltd. Residents reiterated that this was the best possible scenario for all 11 owners at the time. Existing building regulations prohibited partial redevelopment of the project, as that would have required the consent of all 50 owners, which meant the entire project. Conversely, GCCL successfully procured partial redevelopment permission for a commercial project and greatly benefitted from the opportunity to enter the real estate market as a new developer.

All the 11 houses had a road frontage abutting to 40 meters wide road, an excellent opportunity for a commercial project. Siddhivinayak commercial center was constructed, demolishing the 11 houses, while keeping the remaining 39 intact. Doing so allowed the developers to use the common areas which had already existed, including the swimming pool and other amenities. As of today, the remaining house owners share common spaces with the shopping center, much against their residential comfort. The redevelopment of the project required commercial land use permission (No Objection Certificate-NOC) from the existing (remaining 39) house owners before the new project construction was sanctioned. The building drawings submitted to AMC (Ahmedabad Municipal Corporation) required including the entire layout area for the redevelopment. GCCL benefitted from an increased FAR of 1.8, which was 0.8 of the entire land area (all 50 units land), which made it easier for them to negotiate with the remaining 39 owners to secure their NOCs. Eventually it was a win-win scenario for the developers and the remaining 39 unit owners, but not so for the 11 unit owners who suffered from the distressed sale of their properties, fetching what was merely a fair market value.

\subsubsection{Critical Factors}

Urban changes in the city infrastructure and interviews with associated professionals identified critical factors, which included: 1) Land acquisition for public purpose, 2) Building byelaws, 3) Scope of redevelopment, 4) Availability of finance, 5) Abutting road width, 6) Road frontage length of the land parcel.

\subsection{Case Study 3: Town Planning Scheme (TPS) - Prahladnagar}

The case study highlights issues and problems arising due to public land banking using the micro planning - land pooling tool. One needs to research if the local market cycles are influenced by the urban planning initiatives or if the reverse is true.

\footnotetext{
${ }_{1}^{1}$ Also knows as Annual Statement of Rates (ASR) as per Gujarat Land Revenue Department. This is a valuation document of all known urban land parcels within the State of Gujarat, prepared for purposes of Stamp Duty (property transfer tax) collection on their change of use and transfer to another party.
} 


\section{S sciendo}

LAND POOLING \& READJUSTMENT TOOL - TOWN PLANNING SCHEMES, GUJARAT STATE, INDIA
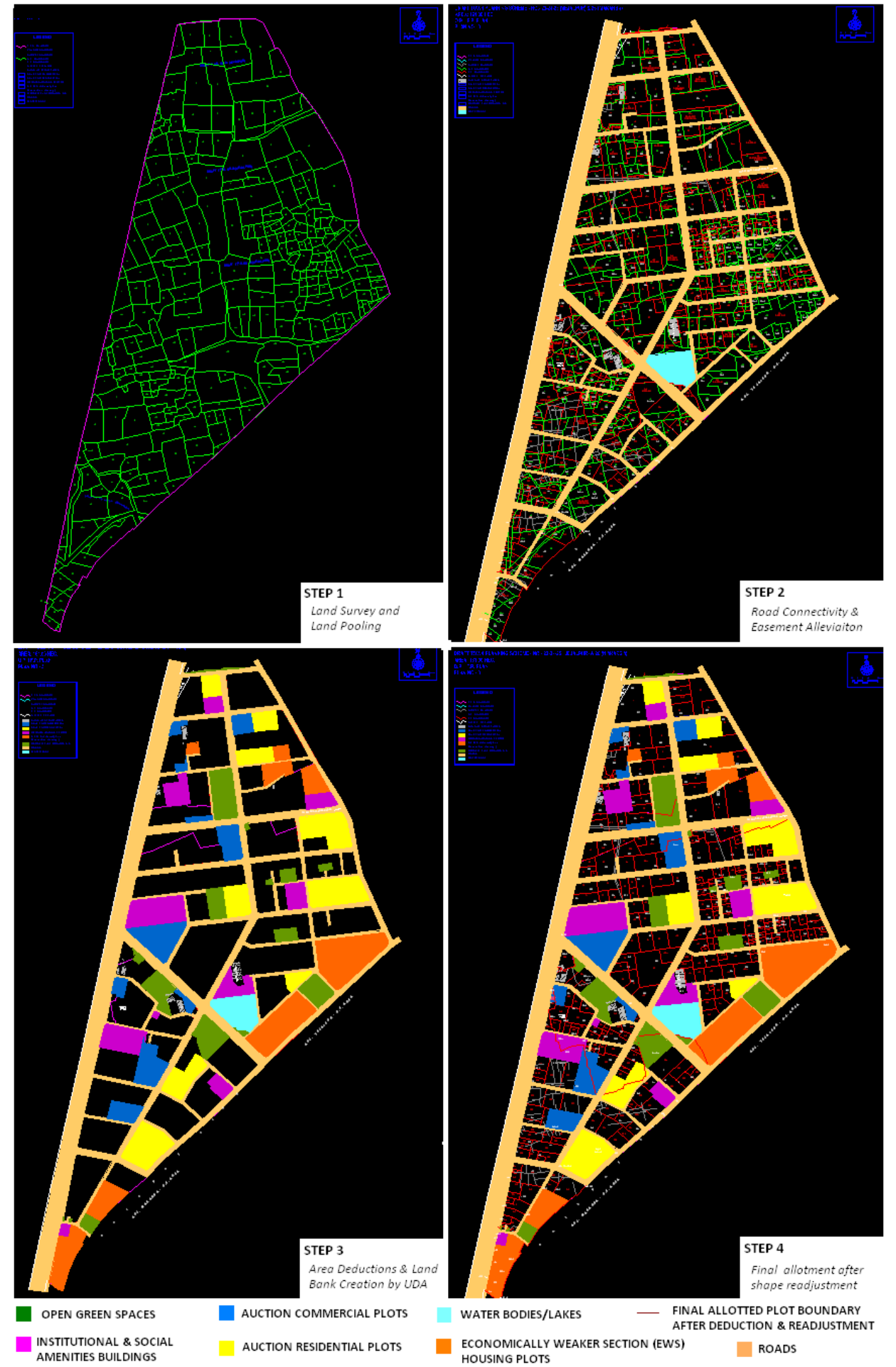

INSTITUTIONAL \& SOCIAL

AUCTION COMMERCIAL PLOTS AMENITIES BUILDINGS

AUCTION RESIDENTIAL PLOTS HOUSING PLOTS

ROADS

Fig: 3: TPS maps of Vejalpur 23, 24, 25 and 26 - Prahladnagar Source: (AUDA, 2015)

\subsubsection{Background of the TPS}

In state of Gujarat, urban bodies and town planning activities are regulated by the Gujarat Town Planning and Urban Development Act, (GTPUDA, 1976) under the provisions of which; Urban Development Authorities (UDAs) and Area Development Authorities (ADAs) are constituted. The role of these bodies is to provide serviced urban land (with paved road network, streetlights, drainage, water supply and electricity services) for developers to build housing, commerce and social amenities. This is achieved by a land pooling and readjustment micro planning mechanism called the

"town planning scheme" (TPS). It also removes all easement rights that may exist on a land parcel as 
all final land plots allotted after readjustment have road access. The TPS mechanism also provides a smooth transition of agricultural land located on the urban fringe which is serviced for urban real estate development.

The TPS is implemented in 3 phases; Draft, Preliminary and Final (AUDA, 2014). Land is pooled, readjusted in size and shape, and returned to the land owners after 30\%-50\% land area deductions. Surveyed land parcels included in the TPS are called Original Plots (OPs) and the returned land parcels are termed Final Plots (FPs). The deducted land is utilized for roads, gardens, open spaces, EWS (Economically Weaker Section) housing, lakes, ponds, recreational spaces, institutional buildings and auction plots - land banked by UDA to recover the costs of implementing the TPS. Land owners benefit from higher land appraisal and pay the incremental value increase tax, also known as a betterment charge. For this reason the TPS model is also known as a PPP (Public Private Partnership) model. Since inception in 1978, AUDA has developed a total of 160 TPS with over 15,500 hectares of total land pooled, readjusted and serviced in the city of Ahmedabad (AUDA, 2017).

Figure 3 shows the physical planning of Vejalpur TPS - 23, 24, 25 and 26 also referred as TPS of Prahladnagar and Makarba, having a land area of 162 Hectares that was pooled, out of which, 51\% of total land was deducted, while $49 \%$ of land was returned the original land (AUDA, 2017). This was the first time in the State of Gujarat when more than $50 \%$ of land was deducted leading to several litigations by the original land owners. On behalf of AUDA the argument was that they wanted to develop a model TPS with more social amenities and a higher percentage of open urban spaces. The TPS was proposed and implemented in the Residential land use zone R1, which has the highest available FAR of 1.8 .

\subsubsection{Status of development}

From year 1978 up to 1999, 162 hectares of land of the TPS were under the reservation of Gujarat Housing Board (GHB) for the purpose of public housing. In year 2001, AUDA published the city's Development Plan, where the entire 162 hectare area had its reservation removed and was incorporated in the R1 (Residential) zone. Moreover, the land on the western side of S.G. Road opposite the TPS was demarcated as an R3 (Residential zone) zone with FAR of 0.3. This meant that the entire pocket of TPS 23, 24, 25 and 26 was poised for the development as per AUDA's urban land use planning strategy.

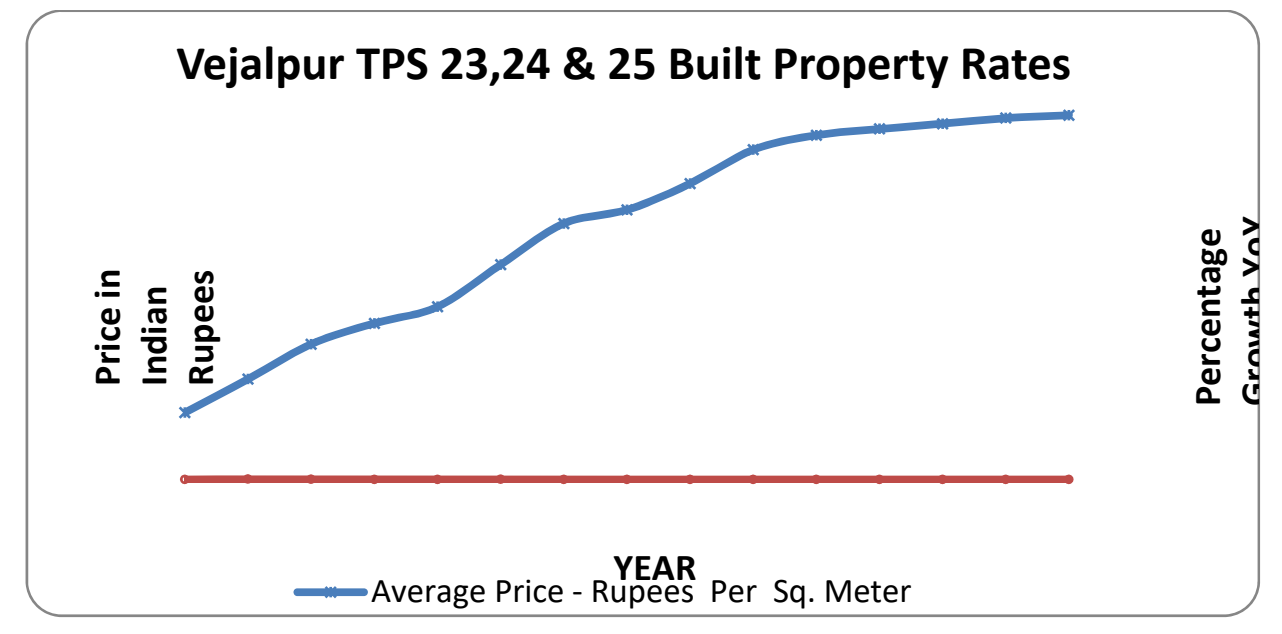

Fig. 4: Price appreciation in Prahladnagar over 15 year span Source: own study.

\subsubsection{Decisions by Stakeholders}

AUDA has been exercising public purpose land banking, like many other planning bodies nationally and globally. The reason for changing the status of the TPS from reservation under GHB to include it in the R1 zone is yet to be ascertained. This was the first instance when a TPS mechanism deducted approximately $51 \%$ of land. The High Court followed by the Supreme Court held the verdict in favour of AUDA against the jointly filed petition by the original land owners of the TPS, who had demanded up to $40 \%$ of maximum land deduction. Allocating the R3 zone (with FAR of 0.3) juxtaposing S.G. Road, opposite the TPS, was a decision which resulted in an increase in land prices. Prime auction 
plots for commercial and residential purposes are yet to be auctioned, land banked with AUDA. Data collected from reliable sources, real estate brokers and practicing developers, excluding TPS 26 (Makarba), showed that real estate property prices increased from an average of 862 INR (Indian Rupees) per $\mathrm{ft}^{2}$ to 3297 INR Per $\mathrm{ft}^{2}$, a cumulative price growth of $282.5 \%$ from the base year 2002 to the year 2008 in TPS 23,24, and 25, as shown in Figure 4.

\subsubsection{Critical factors}

Critical factors which contributed to high appreciation in land prices due to implementation of TPS included; 1) Land banking, 2) Speculation, 3) Neighborhood character, 4) Investment strategy, 5) Project timing and 6) Land use zone status.

Table 1

Critical Factors - Degree of Impact

\begin{tabular}{|c|c|c|c|c|c|c|c|c|c|c|}
\hline \multirow{2}{*}{\multicolumn{2}{|c|}{$\begin{array}{l}\text { Case Studies } \\
\text { Case Study 1: }\end{array}$}} & \multirow{2}{*}{ Symbol } & \multirow{2}{*}{$\begin{array}{c}\text { Categories } \\
\text { Location: }\end{array}$} & \multirow{2}{*}{$\begin{array}{c}\text { Symbol } \\
\nabla\end{array}$} & \multicolumn{6}{|c|}{ Degree of Impact on Development Decision } \\
\hline & & & & & \multirow{3}{*}{$\begin{array}{l}\text { Very } \\
\text { High }\end{array}$} & \multirow{3}{*}{ High } & \multirow{3}{*}{$\begin{array}{l}\text { Mode- } \\
\text { rate }\end{array}$} & \multirow{3}{*}{ Low } & \multirow{3}{*}{$\begin{array}{l}\text { Very } \\
\text { Low }\end{array}$} & \multirow{3}{*}{ weight } \\
\hline Case & Study 2: & $*$ & Project: & $\square$ & & & & & & \\
\hline Case & Study 3: & A & Profession: & $\diamond$ & & & & & & \\
\hline Code & \multicolumn{4}{|c|}{ Critical Factors } & 9 & 7 & 5 & 3 & 1 & Total \\
\hline $\mathrm{Al}$ & \multicolumn{4}{|c|}{ Availability of Land $\nabla$} & $\bullet$ & $\uparrow$ & $*$ & & & 21 \\
\hline $\mathrm{Sp}$ & \multicolumn{4}{|c|}{ Speculation $\diamond$} & 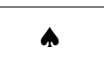 & $*$ & & & $\bullet$ & 17 \\
\hline $\mathrm{Tm}$ & \multicolumn{4}{|c|}{ Timing of Project Announcement $\diamond$} & $*$ & & $\bullet$ & 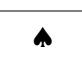 & & 17 \\
\hline Dev & \multicolumn{4}{|c|}{ Neighborhood Character $\nabla$} & & $\bullet$ & $*$ & $\uparrow$ & & 15 \\
\hline $\mathrm{Lb}$ & \multicolumn{4}{|c|}{ Land Banking $\nabla$} & $a$ & & & & $\bullet$ & 11 \\
\hline $\mathrm{Dg}$ & \multicolumn{4}{|c|}{ Design $\square$} & $\bullet$ & $*$ & & $a$ & & 19 \\
\hline Far & \multicolumn{4}{|c|}{ Floor Area Ratio $\square$} & 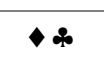 & & & $\uparrow$ & & 21 \\
\hline $\mathrm{Rw}$ & \multicolumn{4}{|c|}{ Abutting Road Width $\square$} & * & $\bullet$ & & & $a$ & 17 \\
\hline $\mathrm{Fl}$ & \multicolumn{4}{|c|}{ Road Frontage Length $\square$} & $*$ & & & $\bullet$ & $a$ & 13 \\
\hline $\mathrm{Rd}$ & \multicolumn{4}{|c|}{ Redevelopment Prospect $\nabla$} & - & $*$ & & & $a$ & 17 \\
\hline $\mathrm{Bv}$ & \multicolumn{4}{|c|}{ Brand Value $\diamond$} & $\bullet$ & * & & & 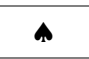 & 17 \\
\hline Pex & \multicolumn{4}{|c|}{ Past Experience of Developer $\diamond$} & & & $*$ & & $\bullet$ & 7 \\
\hline Af & \multicolumn{4}{|c|}{ Availability of Finance $\diamond$} & & $*$ & & & $\bullet$ & 9 \\
\hline $\mathrm{Cp}$ & \multicolumn{4}{|c|}{ Choice of Project $\square$} & $\bullet$ & * & & & A & 17 \\
\hline Laq & \multicolumn{4}{|c|}{ Land Acquisition $\nabla$} & $+a$ & & & & - & 19 \\
\hline Lac & \multicolumn{4}{|c|}{ Land Auctions $\diamond$} & & $\uparrow$ & & & $\leftrightarrow$ & 9 \\
\hline Is & \multicolumn{4}{|c|}{ Investment Strategy $\square$} & & $*$ & $\uparrow$ & $\bullet$ & & 15 \\
\hline Luz & Land Us & Zone $\nabla$ & & & & & 4 & 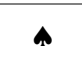 & & 14 \\
\hline & Categori & & & & & & Factors & & & Score \\
\hline 1 & Iocation & & & $L u z$ & $L a$ & $D e v$ & $L b$ & $R d$ & $A l$ & 98 \\
\hline 1 & Location & & & 15 & 19 & 15 & 11 & 17 & 21 & 98 \\
\hline 2 & Proiect & & & $L a q$ & $D g$ & $C p$ & Far & $R w$ & $F l$ & 96 \\
\hline & Project & & & 9 & 19 & 17 & 21 & 17 & 13 & 96 \\
\hline & & & & Is & $S p$ & $B v$ & Af & $P e x$ & $T m$ & \\
\hline 3 & Professic & nal Practic & & 15 & 17 & 17 & 9 & 7 & 17 & 82 \\
\hline
\end{tabular}

Source: own study.

\subsection{Assessment}

A qualitative assessment of factors impacting the case studies is shown in Table 1. The factors are assigned in three categories; 1) Location - Spatial, 2) Project Feasibility and 3) Professional Practice. 
Factors such as Land auctions and investment strategy were also included in the total 18 factor list. These factors were rated for their impact on a scale of 1 to 9 for the degree of impact on each of the case study. Among these, the availability of land ranked highest with a score of 21 while in the category of Project feasibility, FAR ranked highest with score of 21, and, in the third category of professional practice, the factors of speculation, brand value and timing of the project were all ranked highest with a score of 17. The authors' assessment was to form a benchmark to inquire deeper into these factors through further survey.

\subsection{Survey Data Analysis}

A sample survey questionnaire was designed on a 5 point Likert scale where the respondent data was collected using personal and telephonic interviews. The objective of the AHP technique was chosen to shortlist the top rated factors in each category for further research in phase II to study their interrelationship using Pearson's Correlation $r$ and dependency study using the regression models. Due to the limitation of interviewees' time, and seeing as how all the respondents were practicing developers, a 5 point scale was chosen over 7 or 9 point scales. The chosen scale was also assumed to decrease the frustration level and increase the quality of responses for each pair of variables being ranked using the Ratio Scale Method Prioritization (RSMP).

Critical Factors rankings using AHP

\begin{tabular}{|c|c|c|c|c|c|c|}
\hline Code & Critical Factor & Score & $\%$ & $\sigma$ & Rank & Average CR \\
\hline \multicolumn{2}{|c|}{$\nabla$ Location Factors } & & & & & $\begin{array}{c}\text { (Consistency } \\
\text { Ratio) }\end{array}$ \\
\hline Dev & Neighborhood Character & 0.2873 & $28.73 \%$ & 0.090 & 1 & \multirow{6}{*}{0.077} \\
\hline Alp & Availability of Land & 0.2145 & $21.45 \%$ & 0.070 & 2 & \\
\hline Luz & Land Use Zone & 0.1685 & $16.85 \%$ & 0.048 & 3 & \\
\hline$L b$ & Land Banking & 0.1285 & $12.85 \%$ & 0.066 & 4 & \\
\hline Laq & Land Acquisition & 0.1250 & $12.50 \%$ & 0.037 & 5 & \\
\hline \multirow[t]{2}{*}{ Lauc } & Land Auctions & 0.0799 & $7.99 \%$ & 0.039 & 6 & \\
\hline & & 1.0000 & $100 \%$ & & & \\
\hline \multicolumn{7}{|c|}{$\square$ Project Factors } \\
\hline far & Floor Area Ratio (FAR) & 0.2791 & $27.91 \%$ & 0.062 & 1 & \multirow{6}{*}{0.067} \\
\hline$R d$ & Abutting road Width & 0.1841 & $18.41 \%$ & 0.034 & 2 & \\
\hline$F a$ & Frontage length & 0.1687 & $16.87 \%$ & 0.046 & 3 & \\
\hline$C p$ & Choice of project & 0.1587 & $15.87 \%$ & 0.051 & 4 & \\
\hline$B d$ & Building design & 0.1339 & $13.39 \%$ & 0.068 & 5 & \\
\hline \multirow[t]{2}{*}{ Srd } & Scope of redevelopment & 0.0756 & $7.56 \%$ & 0.016 & 6 & \\
\hline & & 1.0000 & $100 \%$ & & & \\
\hline \multicolumn{7}{|c|}{$\diamond$ Professional Practice Factors } \\
\hline Af & Availability of Finance & 0.2271 & $22.71 \%$ & 0.075 & 1 & \multirow{6}{*}{0.061} \\
\hline Tm & Timing of Project & 0.2261 & $22.61 \%$ & 0.055 & 1 & \\
\hline Pex & Past Experience & 0.1893 & $18.93 \%$ & 0.055 & 3 & \\
\hline Bv & Brand Value & 0.1689 & $16.89 \%$ & 0.091 & 4 & \\
\hline Sp & Speculation & 0.0946 & $9.46 \%$ & 0.076 & 5 & \\
\hline \multirow[t]{2}{*}{ Is } & Investment Strategy & 0.0939 & $9.39 \%$ & 0.027 & 6 & \\
\hline & & 1.0000 & $100 \%$ & & & \\
\hline
\end{tabular}

Source: own study.

The total possible respondents for the survey were the 720 actively practicing real estate developers in the city of Ahmedabad (Gihed, 2018). Among these, about 300 members have market experience of more than 15 years, among which there are even fewer of those having a formal college degree. A random sample group, $10 \%$ of the survey sample size (30 respondents) was identified, while ensuring that each respondent in the sampled survey had a formal graduation degree and 15 years of past 
experience. The key underlying assumption for the use of the AHP method was that all the survey participants had a clear understanding of each factor being ranked and compared, without needing to justify or educate them on the differences within each pair, and that they were in the position of making a sound judgment while taking the survey. The survey questionnaire required the developers to rank the critical factors for priority based on the degree of impact each pair had on project decision making. The identified 18 factors were grouped into three categories. Respondents rated a total of 45 pairs, 15 pairs in each of the three categories. The weight matrix and its corresponding consistency ratio were calculated for all 30 responses. Results of the AHP analysis have been summarized and presented in Table 2.

Table 2 shows the corresponding average weights for the factor - Availability for land is 0.215 , which translates to $21.5 \%$ of all the 6 factors. Factors such as Neighbourhood Character, Land acquisition and Land use zones, on the other hand, are averaged evenly, 28.73\%, 15.0\% and $16.4 \%$ respectively. The factor of land auctions $-L u z$ is ranked the lowest of all the factors. Among the Location factors category, the weighted sums of Neighborhood Character (Dev) ranked $1^{\text {st }}$ with $28.37 \%$, while the Availability of vacant land (Alp) ranked $2^{\text {nd }}$ at $21.45 \%$. These two factors alone account to $49.62 \%$ of all 6 factors, with significantly high scores. Project factors averages of weighted sums ranked, FAR (Far) significantly high at $27.91 \%$, followed by road width $(R d)$ and frontage $(F a)$ at $18.41 \%$ and $16.87 \%$ respectively. As compared to the other factors in the group, the scope of redevelopment $(\mathrm{Srd})$ ranked lowest with an average of $7.56 \%$ Professional practice factor averages of weighted sum ranked Availability of finance $(\mathrm{Fa})$ and Timing of project announcement $(\mathrm{Tm})$ highest, at $22.71 \%$ and $22.62 \%$ respectively, as top priority factors in the group. These were followed by Past experience (Pex) and Brand value (Bv), at $18.93 \%$ and $16.89 \%$ respectively. The average consistency ratio (Avg CR) for this set of 6 factors was 0.061 .

\section{Discussion - AHP results}

Investment decisions by an investor with a view to generate profit on the real estate asset as highlighted by Klimczak were divided into 3 broad compartments; 1) land, 2) foundation and superstructure, and 3) future appreciation of the property (Klimczak, 2010). In our study, while land and location prove highly critical, project factors such as FAR, abutting road width and road frontage are driving the project decisions. Developers often resort to the presale of real estate projects. This is a common practice in south Asian countries, done primarily to hedge the risks connected with competition. It creates a barrier protecting from the entry of new developers; markets are oligopolistic in nature and are often dominated by developers who have access to large capital for investment and holding (Lai et al., 2004). The Availability of finance and timing of project - ranked highest in the professional practice category, which corroborates the research findings of Lai et al. (2004).

Developers choose to exercise the "Option to Wait" strategy by delaying the project when the real estate market is slow and sales are bleak (Somerville, 2001). Developers are likely to sell initial units at a lower price when they are not aware of the neighborhood changes and land market conditions. As the project proceeds, they are likely to sell the units at a higher rate by observing the changes in the neighborhood (Schwartz \& Torous, 2003). While our study does not include the factors aligned to customer participation in the project, developers downplayed the importance of investment strategy (Is) which was ranked lowest among all professional practice factors at $9.39 \%$, just below speculation at $9.46 \%$. Developers buy land and announce a project based on their corporate strategy, but are heavily dependent on factors such as availability of land, finance and timing of their investment.

In the category of professional practice, three factors; Availability of finance, Timing of project announcement and Past experience of developers, make for $65 \%$ of the total weight in the AHP score, which is $2 / 3^{\text {rd }}$ of all six factors combined. Availability of finance scores high - studies in countries like Nigeria highlight that the increase in lending rates and high inflation in growing economies put real estate markets at higher capital risks, even in conditions when markets have high liquidity (Ogedengbe \& Adesopo, 2003). Timing the project in optimum market conditions can lead to quicker recovery of the investment (Mueller, 2002). Developers who responded to our survey believe that having past experience of similar projects and understanding market conditions is an important factor in successful project execution. Critical factors with top three ranks and prioritization were deemed eligible for further analysis, as all top ranked factors constituted close to $66 \%\left(2 / 3^{\text {rd }}\right)$ of aggregate weight in their respective groups. However, Land use zone in the location group would have had the same measurement as FAR; which is indicative of its impact. 
High priority is given to factors of neighborhood character and the availability of land in the category of location. These results are significant as the scarcity of urban land has been an observed issue in real estate development due to the issues of land titles, reservation of land by local urban bodies and delayed revisions of Development Plans (in case of AUDA), which are carried out every 10 to 12 years. The growing economy of cities of India require the updating of planning goals every 5 years, due to rapid changes in the urban dynamics. Unauthorized developments, such as "slums", also contribute to the scarcity of urban land. For this reason, developers may acquire land, when available, given the situation they agree on the financial terms, with a pretext of proposing a project in future - a situation wherein the feasibility of the choice of a project is carried out later. Such a market behavior can be in huge contrast with other countries where the choice of a project precedes land acquisition. In a Dutch study, it was pointed out that, when availability of land is scarce, when two land parcels of equal size are transacted, the parcel having the higher land price takes precedence in the valuation market, thus increasing the price of land acquisition (Woestenburg, 2014). Similarly, in the expansion phase of a market, multiple land deals in a short period can skyrocket land prices in a given neighborhood. A recent study done in Melbourne, Australia confirms that both the local planning authorities and developers play a vital role in shaping the built environment, and this interdependence leads to creating a neighborhood character, making it a vital factor in city development (Tewari \& Beynon, 2018). In our survey, with a contribution of nearly $50 \%$ of weight in the category of six factors, both the availability of land and neighborhood character were considered for further research analysis

\subsection{Discussion on Case studies}

Case study of Patang Restaurant (Case Study 1) highlights the importance for developers to have the option of executing a new development for real estate land and ability to benefit from existing building regulations available in the urban zone and leverage on the increased FAR. Developers value their brand in the local market and are willing to invest in it for long term profits. A study on housing characteristics reveal that, empirically, the structural characteristics of a property (house) has low association with bargaining outcome, while the location had a significant impact on negotiations as a factor (Semeraro \& Fregonara, 2013). It is also important to state that there have been observations whereby the developers are also dependent on the nature of the transaction on the price which allows them to settle informal fianances (cash) over and above the Highest and Best Use value for the property. Similar findings (Gaca, 2019 ) suggest that "The prices analyzed must be examined not only in terms of their causal relationship with the characteristics of the property and the state of the market, but also in respect to the terms and conditions of the contract".

Siddhivinayak Commercial Centre (Case Study 2) was a profitable venture, allowing the developer to gain up to $900 \%$ returns on their initial investment. As a policy, the urban civic authority (Ahmedabad Municipal Corporation) does not permit redevelopment unless the previous structure is totally demolished. However, due to the special case connected with road widening however, permission for partial redevelopment was granted. This case study is an example on how intangibles such as a change in planning regulations, land acquisition and loss of partially built-up to housing can alter the land dynamics for existing properties in a rapidly urbanizing neighborhood. A study on public private brownfield redevelopment project in Catalonia, Spain, (Marmolejo-Duarte \& RuizLineros, 2013) shows that conjoint analysis, a technique often used for designing goods and services by means of future user/consumer participation, may be used as a support tool in making real estate decisions. Use of such a technique could have helped the existing residents of Jay Shefali row houses, whereas the Siddhivinayak Commercial Center could have used a more inclusive design approach to benefit all.

AUDAs successfully implement the TPSs, but their efficacy can only be complimented by the developers' willingness to enter the market (Case Study 3). As a result, some TPS may see urban development faster when compared to others. It is observed that TPS are not timed as per the market cycle and are based on the urban planning needs of the city. However, a spurt of urban activity is evident invariably when TPSs are announced and drafted. With this in place, established and proficient developers resort to land banking by which they acquire rural-agricultural land located at a moderate distance from the urban fringe. Developers speculate that these lands will be included within the perimeter of the upcoming Urban Development Plan and TPS. Developers await the announcement of a TPS which will help increase the land value and also allow them to maximize their 
investment returns. Several State and Country Governments have now shifted to an alternative approach of achieving development objectives for public purposes using subtle land banking options and PPP (Public Private Partnership) models such as land assembly (Louw, 2008), urban service boundary (Smersh \& Smith, 2002), transfer of Development Rights (Thornes \& Gerald, 1999) and Land Pooling Systems (Mathur, 2012). Developers are known (Yang, Wu, 2019) to postpone land development decisions after land acquisition to recover prior loses attributing to their varying risk taking attitudes.

One of the key roles played by AUDA is to provide efficient land use by making the city compact and suitable for urban development (Adhvaryu, 2011); despite this, their land banking strategy does not appear to be aligned with these objectives. The role played by AUDA is that of a facilitator of serviced urban land, land banker for public purpose amenities and controller of pockets of neighbourhoods where real estate markets are likely to flourish.

Internationally, Governments have been actively resorting to land banking for public purpose. Land banking mechanisms are widely practiced in over 1,600 cities or counties in China. "The concept has its origin in the city of Amsterdam, in Netherlands in late 1890's. Land banking was also adopted by several western countries such as Sweden (since 1904), Canada (since 1950's) and France (since 1958) during the last century. And since the 1970s several pilot projects of public land banking were carried out in some American cities".

\section{Conclusions}

We conclude that, among critical factors, those of speculation $(9.46 \%)$, brand value $(16.89 \%)$ and Investment Strategy $(9.39 \%)$ were lowly prioritized when compared to the availability of finance $(22.71 \%)$, project timing $(22.61 \%)$ and past project experience $(18.93 \%)$, among the professional practice category with an average Consistency Ratio of 0.077 . The brand value of a company is an added advantage in achieving sales, but not considered a high impact factor while making project decisions. Similarly, an investment strategy formulated by an individual company is likely to be based on the availability of finance, which was ranked highest in this category. Speculation may drive investment decisions, but may not be critical in project planning and execution. Among the project factors category, building design (13.39\%) and the scope of redevelopment $(7.56 \%)$ were ranked much lower than FAR $(27.91 \%)$ and abutting road width $(18.41 \%)$ in the location Category with an average consistency ratio of 0.067 . Developers are more likely to choose to build on vacant land as compared to redeveloping an existing project. Their choice of investment is driven by the FAR available and abutting road width on the land while commissioning a project. Neighborhood character $(28.73 \%)$ and availability of land $(21.45 \%)$, ranked higher than factors such as land auctions $(7.99 \%)$ and land banking $(12.85 \%)$ in the location category, with an average consistency ratio of 0.077 . Developers are likely to use land as a resource for project development and not resort to land banking (holding) while making project decisions. It further proves that developers prefer buying freehold land; decisions were based on a neighborhood character, such as not opting to buy from land auctions, as this requires higher formal (Pandya \& Patel, 2017) capital compared to market buying.

\section{References}

Ogedengbe, P. S., \& Adesopo, A.A. (2003). Problems of Financing Real Estate Development in Nigeria. Journal of Human Ecology (Delhi, India), 14(6), 425-431. https://doi.org/10.1080/ 09709274.2003.11905648.

Adhvaryu, B. (2011). Ahmedabad Urban Development Plan Making Process. Planning Practice and Research, 26(2), 229-250. https://doi.org/10.1080/02697459.2011.560463

Ahluwalia, I., \& Kanburand, R. (2014). Planning for Urban Development in India. ICRIER- Sage Publication.

AMC. (2018). Demographics: Ahmedabad. Retrieved November 15, 2018, from ahmedabadcity.gov.in: https://ahmedabadcity.gov.in/portal/jsp/Static_pages/demographics.jsp.

AUDA. (2017). TP Scheme. Retrieved December 9, 2018, from Ahmedabad Urban Development Authority: http://www.auda.org.in/TPScheme.aspx.

AUDA. (2014) AUDA. Retrieved June 15, 2015, from AUDA: http://www.auda.org.in/uploads/Assets/rdp/finalgdcrsection171c702062016044746423.8.15.pdf

Batra, L. (2009). A Review of Urbananization and Urban Plicy in Post-Independant India. CSLG- JNU. 
Bholey, M. (2016). India's Urban Challenges and Samrt Cities: A Contemporary Study. Scholedge International Journal of Business Policy \& Governance, 3(3), 7-38.

Bokhari, G. (2014). Characteristics of Depreciation in Commercial and Multi-Family Property: An Investment Perspective. Center for Real Estate at MIT.

Bucheli, G. (2016). Application of Analytic Hierarchy Process in the construction Industry: A case study in the selection of the plot for real estate project. International Conference on Electrical Engineering and Inforamtion Technology, 63, 235-243.

CMHC. (2014). Retrieved 2016, from Canada Mortgage and Housing Corporation: https://www.cmhcschl.gc.ca/en/inpr/afhoce/afhoce/tore/hodefashch/upload/building_site_selection_EN.pdf

CRISIL. (2007). Methodologies for Valuing. CRISIL.

Crosby, N., \& Devaney, S. (2011). Benchmarking and valuation issues in measuring depreciation for European office markets. Journal of European Real Estate Research, 4(1), 7-28.

Devaney, S. (2014). Measuring European property Investment Performance: Comparing Different Approaches. Journal of European Real Estate, 7(1), 112-132. https://doi.org/10.1108/JERER-10-20130022.

Gaca, R. (2019). Price as a Measure of Market Value on the Real Estate Market. Real Estate Management and Valuation, 26(4), 68-77.

GIHED. (2018). Memberships. Retrieved July 3, 2018, from Gujarat Institute of Housing and Estate Developers: http://gihedcredai.org/membership.php.

Grzesik, K. (2014). Równi wspóttwórcy w opracowywaniu standardów wyceny - Instytut Oceny i Wyceny Przychodów (IRRV). Equal Bedfellows in Developing Valuation Standards - The Institute of Revenues Rating and Valuation. IRRV.

Grzesik, C., \& Źróbek, S. (2017). Zmiana pozycji w zakresie wartości nadziei, zarządzania nieruchomościami i wyceny. [Shifting Positions on Hope Value]. Real Estate Management and Valuation, 25(3), 23-29. https://doi.org/10.1515/remav-2017-0019

HCP. (2014). hcp limited. Retrieved from hcp, HCP Design, Planning and Management Pvt. Ltd.

Jansen, M., \& Mills, E. S. (2013). Distortions Resulting from Residential Land Use Controls in Metropolitan Areas. Journal of Real Estate Economics, 46, 193-202. https://doi.org/10.1007/s11146011-9310-7.

Kamal Mngaldas. (2014). Kamal Mangaldas Architects. Retrieved November 16, 2014, from http://kamalmangaldas.net/project/jai-shefal-park.

Klimczak, K. (2010). Determinants of Real estate Investment. Economia e Sociologia, 3(2), 58-66. https://doi.org/10.14254/2071-789X.2010/3-2/6.

Louw, E. (2008). Land Assembly for Urban Transformation - The case of Hertogenbosch in Netherlands. Land Use Policy, 25(1), 69-80. https://doi.org/10.1016/j.landusepol.2006.09.002.

Malpezzi, S., \& Wacher, S. M. (2002). The Role of Speculation in Real Estate Cycles (working paper). Wisconsin: The Center for Urban Land Economics Research.

Marmolejo-Duarte, C., \& Ruiz-Lineros, M. (2013). Using Choice-Based-Experiments to Support Real Estate Design Decisions. Journal of European Real Estate, 6(1), 63-89. https://doi.org/10.1108/ 17539261311312979.

Mathur, S. (2012). Use of Land Pooling and Reconstitution for Urban Development: Experiences from Gujarat, India. Habitat International, 38(10), 1016-1022.

Mills, E. (2009. Urban land-use controls and the subprime mortgage crisis. The Independent Review, 13(4), 559-565.

Mintah, K. (2018). Real Options Analysis in Residential Property Development Decision-Making in Australia: Perspectives of Executives. International Real Estate Review, 21(4), 473-520.

Mueller, G., (2002). What will the Next Real Estate Cycle Look like? Journal of Real Estate Portfolio Management, 8(2), 115-122.

Pagourtzi, E., Assimakopoulos, V., Hatzichristos, T., \& French, N. (2003). Real Estate Apppraisal: A review of Valuaiton methods. Journal of Property Investment \& Finance, 21, 383-401. https://doi.org/10.1108/14635780310483656.

Pandya, J., \& Patel, V. (2017). Real Estate Market Forecast - Post Demonetisation in India. International Journal o Creative Research Thoughts, 5(4), 1279 -1285. 
Lai, R. N., Wang, K., \& Zhou, Y. (2004). Sale before Completion of Development: Pricing and Strategy. Real Estate Economics, 32, 329-357. https:// doi.org/10.1111/j.1080-8620.2004.00094.x

Rowley, J. (2002). Using Case Studies in Research. Management Research News, 25(1), 16-27. https://doi.org/10.1108/01409170210782990.

Schwartz, E., \& Torous, W. (2003). Comemercial Office Space: Tests of a Real Operations Model with Competitive Interactions. (Working Paper). California, USA: University of California - Los Angeles.

Semeraro, P., \& Fregonara, E. (2013). The Impact of House Characteristics on the Bargaining Outcome. Journal of European Real Estate, 6(3), 262-278. https:/ / doi.org/10.1108/JERER-12-2012-0030

Smersh, G. T., \& Smith, M. T. (2002). Factors Affecting Residential Property Development Patterns. American Real Estate Society annual conference. Florida.

Somerville, C. (2001). Permits, Starts and Completions: Structural Relationships versus Real Options. Real Estate Economics, 29(1), 161-190. https:// doi.org/10.1111/1080-8620.00006.

Szczepańska, A. (2012). Czynniki niematerialne, które kształtują indywidualne podejście do optymalnego wykorzystania nieruchomości, badań i materiałów towarzystwa nieruchomości (Intangible factors that shape an individual approach to the optima use of real estates). Studies and Materials of the Real Estate Society, 20(2), 167-175.

Teegavarapu, S., \& Summers, J. D. (2008). Case Study Method for Design Research. ASME International Design Engineering Technical Conferences, New York: DETC.

Tewari, S., \& Beynon, D. (2018). Changing Neighbourhood Character in Melbounre: Poing Cook a Case Study. Journal of Urban Design, 23(3), 456-464. https://doi.org/10.1080/ 13574809.2017.1383152.

Thornes, P., \& Gerald, S. P. (1999). Letting the Market preserve Land: The Case for a market-Driven transfer of Development Rights Program. Contemporary Economic Policy, 17(2), 255-266.

Woestenburg, A. (2014). The Issue of Value and Price in Land Market Research. FIG Congress, Kuala Lumpur.

Yang, Z., \& Wu, S. (2019). Land Acquisition Outcome, Developer Risk Attitude and Land Development Timing. The Journal of Real Estate Finance and Economics, 59(2), 233-271. https://doi.org/10.1007/s11146-018-9663-2. 